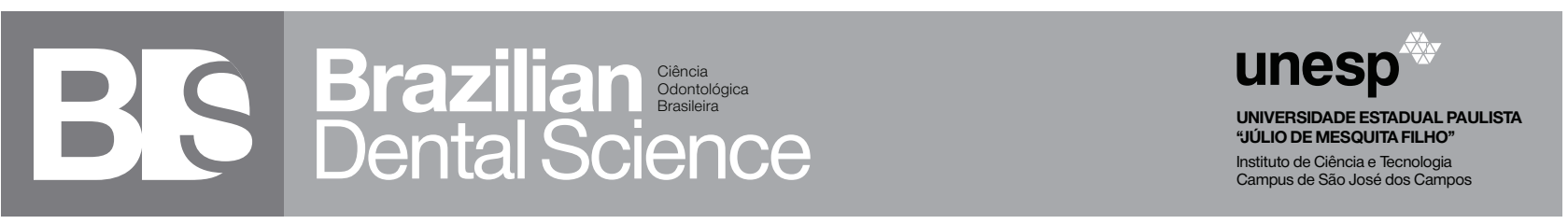

doi: 10.14295/bds.2015.v18i2.1154

\title{
EDITORIAL
}

\section{COAT - THIRTY YEARS OF OROFACIAL PAIN HISTORY IN BRAZIL}

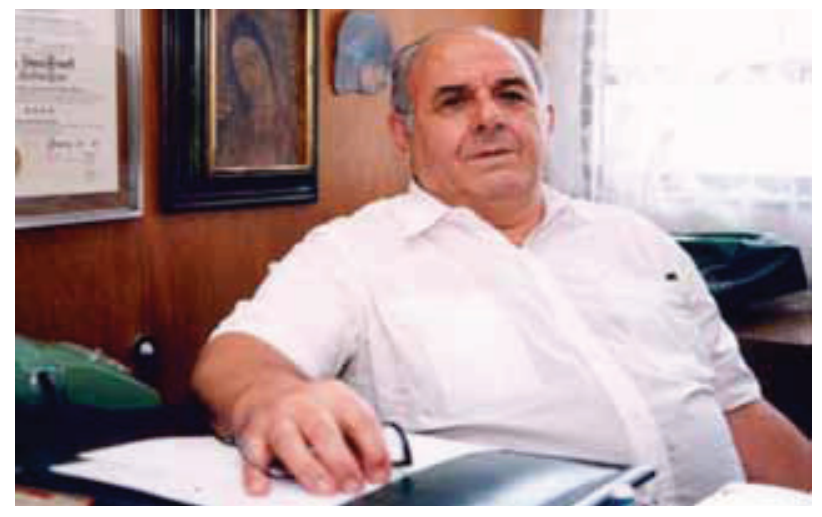

Dr. Brunetti, an altruistic person, was at the forefront and always ahead of his time. He, in a period lacking of professionals prepared to deal with orofacial pain, aimed at the well-being and relieve of pain of others.

Next August, COAT - the "Center for Occlusion and Temporomandibular Joint", at the Institute of Science and Technology, is celebrating 30 years. The center was established by Prof. Ruy Fonseca Brunetti, with the collaboration of local Professors Benedicto José de Mello, Maria Amelia Maximo de Araujo, Fernando Takahashi and collaborating dentists Rosa Maria Assis Vilela, José Rubens Cavalca and Wagner Pinto de Oliveira, being a pioneer center within Brazilian dentistry.
Dr. Brunetti, an altruistic person, was at the forefront and always ahead of his time. He, in a period lacking of professionals prepared to deal with orofacial pain, aimed at the well-being and relieve of pain of others. His purposes were based on a tripod: to assist the population, to form a multidisciplinary team and to promote technical and scientific development.

Since 1985, the center has assisted thousands of patients, mainly from Paraíba Valley area, south of Minas Gerais, São Paulo and Rio de Janeiro.

The center has favored the formation of a multidisciplinary team, in partnership with medical, psychology, speech therapy and physiotherapy professionals. Thus, different areas began to understand the same language, to assess the individual from different aspects, resulting in unquestionable benefits for patients with orofacial pain. More than 250 professional coming from different parts of Brazil have studied in our center. At the end of their internships, they have shared with their communities their new experience and knowledge, geometrically expanding the assistance to the population.

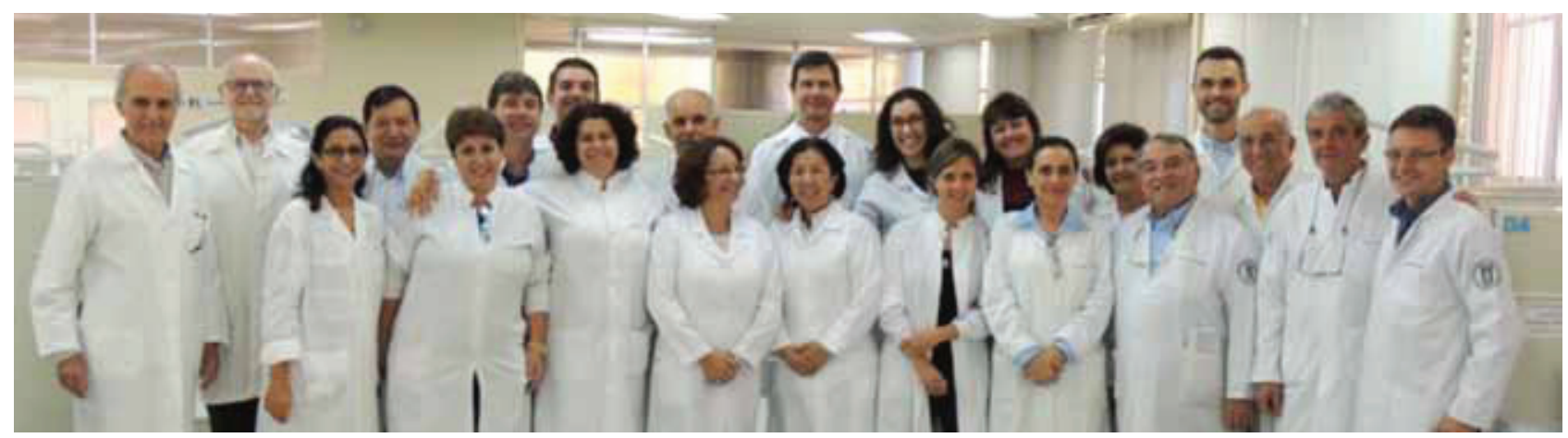


Third, scientific publications might have been indirectly reaching professionals settled in distant places of this country of continental dimensions. Several masters' dissertations and $\mathrm{PhD}$ theses were performed based on the population/data of our clinics. Our experience has been widespread at non-scientific and scientific levels, through papers presented at conferences, workshops and meetings throughout the country, nationally projecting the name of our School.

Our team have articles published in national and international journals, book chapters and a book that summarizes our clinical experience, "Disfunções Temporomandibulares" published by Editora Artes Médicas “.

During the process of creating the specialty by the CFO in 2002, our book was one of the references for the exam to qualify the first specialists in Temporomandibular Disorders (TMD) and Orofacial Pain (OFP).

Over time, another Dr. Brunetti's dream was accomplished: to offer TMD and OFP course for undergraduate students. Although Occlusion and Temporomandibular dysfunction was a regular subject, it was superficially present in different disciplines, especially in Physiology, Operative Dentistry and Restorative Dentistry, lacking uniform concepts, uniformity in teaching and curriculum. This practice over time proved to be not practicable, with considerable damage to undergraduate students, who were exposed to multitude of concepts, methods and techniques, duplication of classes and loss of precious time, reflecting in scarce employment at the end of the course. The dean of the institute, knowing this fact and taking advantage of the experience of the center, has promoted the TMD course to an extra-curricular theoretical and clinical subject for the senior dental students. At the beginning the subject was taught at periods out of the schedule, none of students failed to attend it. The School Assembly, taking into consideration students' attendance and the importance of the subject, promoted it to a regular subject in the curriculum in 2000. Once again our School pioneered within this point. Nowadays, the TMD specialty exists and the subject is taught in several dental schools, although still being optional in some.

The undergraduate course aims to train students, both in theory and in laboratory settings, on the principles of occlusion, TMD and OFP, making them proficient in the diagnosis and treatment of pathological processes of the stomatognathic system: muscles, TMJ, teeth, periodontium and associated structures, enabling them to assist patients in the clinical setting.

Thus, we have closely followed the evolution of this area in the last 30 years, about the etiological aspects, the pathophysiology and therapies. We have experienced different currents that justify the initiation of dysfunction. In the 80s, there were still remnants of occlusion followers, for whom the stomatognathic system disorders had originated in occlusion imbalances. Unfortunately, many occlusion rehabilitations were unnecessarily performed and adjustments by selective grinding were indiscriminately carried out with high iatrogenic potential, if not innocuous.

In the early 90s, the concepts of Evidence Based Medicine emerged. These concepts were based on randomized and double blind studies, leading the medical research with a more scientific aspect, and conceptualizing more realistically the TMD problem. Thus, the biopsychosocial model arises. This model considers the biological, psychological and sociological issues as body systems, and the cardiovascular or musculoskeletal systems with no separation from the mind and body. Recently, other models are being designed, as proposed by the OPPERA project (Orofacial Pain: Prospective Evaluation and Risk Assessment). This project incorporates new approaches, considering the amplification of pain as a major factor in its persistence. It indicates a relationship not only between the 
physical, psychological and environmental, but how neurotransmitters and genetic components would interact.

The evolution of physiology and neurophysiology significantly contributed to understanding the pathophysiological processes in myalgias. It became clearer how different stages of muscle changes occur and how, through the neurogenic inflammation, aseptic inflammation processes settle.

In the 80s, myofascial dysfunctions were only observational phenomena. Nowadays, the evolution of biochemical methods and sophisticated imaging processes can confirm theories that were mere assumptions.

The imaging capabilities that we had 30 years ago were limited and TMJ transcranial radiographs were part of our protocol. There were few CT scanners and prices limited their use. In present time, Cone Beam images are very precise and allow three-dimensional reconstruction of hard tissues of the cervical-cranial structures, while Magnetic Resonance Imaging allows the visualization of soft tissues. This technology is available for accessible cost to a greater number of locations. Diagnosis became more precise, prognosis more realistic, and treatments became more specific.

The repositioning plates of the articular disc, extensively used in the past, have now restricted indication for selected scenarios. Paradoxically, relaxation bite plates remain widely used, although its action mechanism is not clear yet. It can also be said that, by their popularity, bite plates are overemployed, negatively affecting the prognosis of other specific disorders, in which other methods of treatment are the first choice. Unfortunately, the disassociation of occlusion as an etiologic factor of TMD, many authors despised the criteria for preparation of occlusal bite plates, as the use of articulator for the waxing and adjustments. Experienced professionals have the perception these opinions are just to highlight that occlusion is not the trigger (but can be a perpetuating factor) of TMD. However, this fact could be dangerous for beginners in the profession and might produce iatrogenesis in poorly balanced plates.

The evolution of neurophysiology allowed us to reasonably understand the influence of central sensitization in pain chronification. The chronification takes place in the second order neuron at the dorsal horn of the spinal cord or its equivalent in the sensitive trigeminal nucleus. A suprasegmental nonregulation of endogenous systems of pain modulation in the brain and encephalon allows chronification of pain. The three main ways to stimulate the nuclei suppressors pain are tricyclic antidepressants, acupuncture and TENS. They all modulate pain at segmental level by descendant stimuli from suprasegmental cores: We recommend that healthcare professionals involved in the treatment of pain know these three techniques to apply them or to refer to qualified professionals.

The future perspectives of the specialty will target more accurate differential diagnosis, with better understanding of etiological factors and more accurate images. A better prognosis will depend on the progress of neurophysiology and pharmacotherapy. Dentists will continue to be the responsible professionals, although multidisciplinary team will be increasingly required for the management of Orofacial Pain.

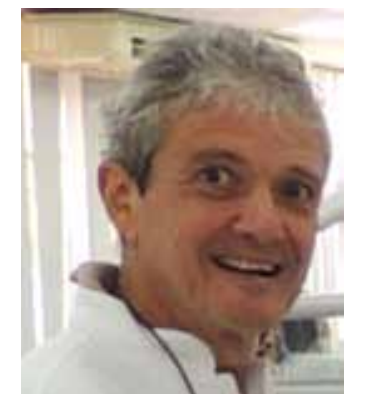

Prof. Dr. Wagner Oliveira 


\section{EDITORIAL}

\section{COAT - THIRTY YEARS OF OROFACIAL PAIN HISTORY IN BRAZIL}

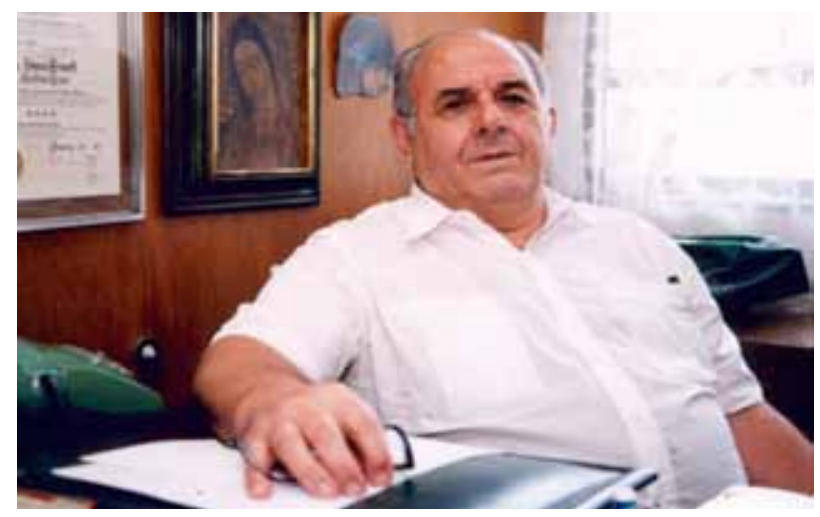

Dr. Brunetti, an altruistic person, was at the forefront and always ahead of his time. He, in a period lacking of professionals prepared to deal with orofacial pain, aimed at the well-being and relieve of pain of others.

No próximo mês de agosto de 2015 a Faculdade de Odontologia de São José dos Campos estará comemorando 30 anos da criação do COAT - "Centro de Oclusão e Articulação Temporomandibular". O Prof. Ruy Fonseca Brunetti com a colaboração dos doutores José Benedicto de Mello, Maria Amélia Máximo de Araujo, Fernando Takahashi, professores desta unidade, e dos colaboradores, Rosa Maria Assis Vilela José Rubens Cavalca Pinto e Wagner de Oliveira, criou este Centro, pioneiro na Odontologia Brasileira.
Na vanguarda, sempre à frente do seu tempo, numa época carente de profissionais preparados para lidar com dor orofacial, o Dr Brunetti, de personalidade altruísta, tinha como objetivo o alivio da dor e o bem estar do próximo. Seus propósitos baseavam-se num tripé: atender a população, formar uma equipe multidisciplinar e promover desenvolvimento técnico-científico.

Assim desde 1985, o Centro já atendeu milhares de pacientes, vindos principalmente do Vale do Paraíba, Sul de Minas, São Paulo e Rio de Janeiro.

Privilegiou a formação de equipe multidisciplinar, em parceria com a área médica, psicologia, fonoaudiologia e fisioterapia. Com isso, áreas diferentes passaram a falar a mesma língua, ver o indivíduo sob ângulos diferentes e com benefícios indiscutíveis para os pacientes com dor orofacial. Já estudaram em nosso Centro mais de 250 profissionais, vindos de diferentes lugares do Brasil que ao término de seus estágios, têm levado às suas comunidades a experiência adquirida conosco e compartilhando seus conhecimentos, ampliam geometricamente a população beneficiada.

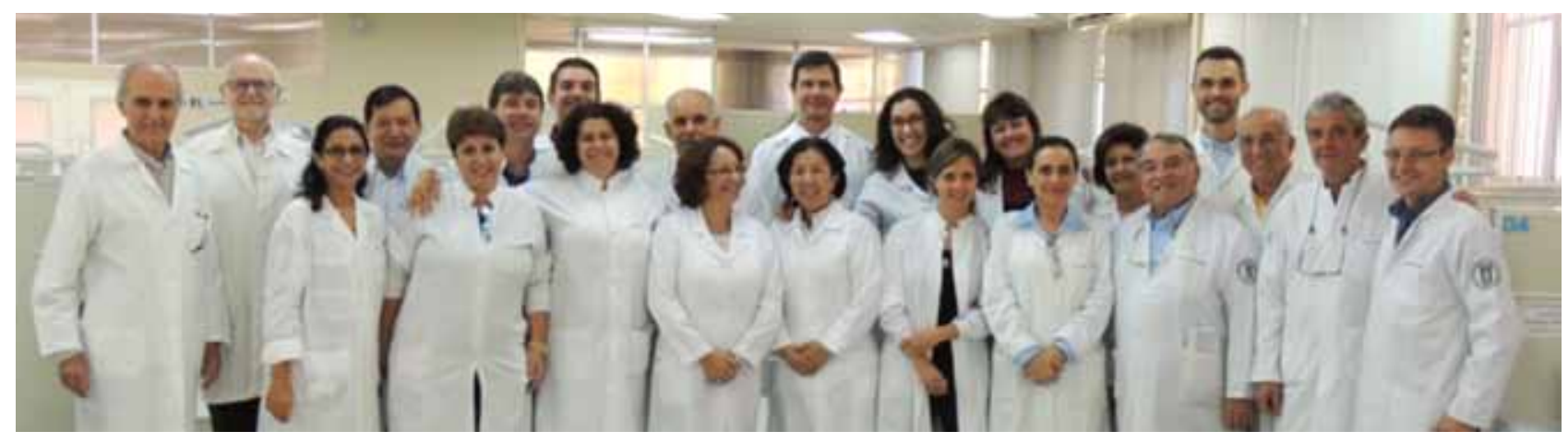

COAT TEAM - 2015 
Em terceiro lugar, pela produção de material escrito, em publicações científicas, poderíamos alcançar, sem contato direto, profissionais em locais distantes deste pais de dimensões continentais. Utilizando amostras de nossa clínica, diversas dissertações de mestrado e doutorado foram realizados. Nossa experiencia tem sido divulgada tanto no meio leigo como no científico, através de trabalhos apresentados em congressos, jornadas e ciclos de conferências por todo o país, projetando nacionalmente $\mathrm{o}$ nome da nossa Faculdade.

Nossa equipe produziu artigos publicados em revistas nacionais e internacionais, capítulos de livros e um livro que resume nossa experiência clínica: "Disfunções Temporomandibulares" publicado pea Editora Artes Médicas".

Durante o processo de criação da especialidade, pelo CFO em 2002, nosso livro foi uma das referências para o exame que qualificaria os primeiros especialistas em Disfunções Temporomandibulares (DTM) e Dor Orofacial (DOF).

Com o tempo, mais um sonho do Dr. Brunetti foi concretizado: oferecer uma disciplina de DTM e DOF para os alunos de graduação. Embora fosse matéria programática, Oclusão e Disfunção Temporomandibular estivesse presentes, de forma superficial, em diferentes disciplinas, especialmente na Fisiologia, Odontologia Restauradora e nas disciplinas de Prótese Dentária, não existia unanimidade de conceitos, uniformidade de metodologia de ensino e conteúdo programático. Esta prática, no tempo, mostrou-se inexeqüível, com prejuízo considerável para os alunos do curso de graduação, que expostos a uma multiplicidade de conceitos, métodos e técnicas, duplicação de aulas e perda de tempo precioso, refletia em escasso aproveitamento no final do curso. A direção FOSJC, sensibilizada com o fato e aproveitando a experiência adquirida pelo Centro, passou a oferecer em caráter extra- curricular um curso teórico-clínico de DTM aos alunos cursantes do último ano letivo. Apesar de no ínicio ser uma disciplina optativa, em horário fora da grade oficial, nenhum aluno matriculado na Faculdade deixou de freqüentála. Com esta adesão, a Congregação da nossa escola, reconhecendo a importância do assunto, oficializou curso na grade curricular em 2000. Mais uma vez nossa Escola foi pioneira, na vanguarda da Odontologia Brasileira. Hoje, por existir a especialidade, diversas Faculdades de Odontologia passaram a oferecer um curso de DTM e DOF, embora algumas ainda como curso optativo.

O curso aos alunos de graduação tem por finalidade habilitá-los por meios teóricos e laboratoriais a dominar os princípios básicos da oclusão, DTM e DOF tornando-os proficientes no diagnóstico e no tratamento dos processos patológicos que envolvem o Sistema Estomatognático: músculos, ATM, dentes, periodonto e estruturas associadas, capacitandoos ao atendimento ambulatorial de pacientes.

Portanto, temos acompanhado de perto a evolução que esta área teve nos últimos 30 anos, nos aspectos etiológicos, nos mecanismos fisiopatológicos e na terapêutica.

Vivenciamos diversas correntes que justificavam o desencadeamento das disfunções. $\mathrm{Na}$ década de 1980 ainda havia os resquícios dos oclusionistas, para quem os distúrbios do Sistema Estomatognático tinha origem nos desequilíbrios da oclusao. Infelizmente muitas reabilitações oclusais foram realizadas desnecessariamente e ajustes por desgaste seletivo foram realizados de forma indiscriminada com alto potencial de iatrogenia, quando não inócuos.

No início dos anos 90 surgiram os conceitos da Medicina Baseada em Evidência, que com trabalhos randomizados, duplo cegos, passou a tratar as pesquisas na área de saúde de forma mais científica, conceitualizando mais 
realísticamente o problema das DTMs. Assim surge o modelo biopsicosocial que considera as questões biológicas, psicológicas e sociológicas como sistemas corporais, assim como o sistema cardiovascular ou musculoesquelético sem separação entre mente e corpo. Nos dias atuais outros modelos estão sendo desenhados, como o proposto pelo projeto OPPERA (Orofacial Pain: Prospective Evaluation and Risk Assessment), que incorpora novas abordagens, considerando a amplificação da dor como o principal fator na sua persistência e indica um relacionamento não apenas entre as variáveis físicas, psicológicas e ambientais, mas como os neurotransmissores e componentes genéticos podem interagir.

A evolução da fisiologia e neurofisiologia contribuíram significativamente para a compreensão dos processos fisiopatológicos das mialgias. Tornou-se mais claro como os diferentes estágios das alterações musculares ocorrem e como que, por intermédio da inflamação neurogênica, os processos inflamatórios assépticos se instalam.

Na década de 80 as disfunções miofasciais eram apenas fenômenos observacionais, hoje com a evolução de métodos bioquímicos e sofisticados exames de imagem se pode confirmar teorias que eram meras hipóteses.

Os recursos de imagens que tínhamos há 30 anos eram limitados. Fazia parte do nosso protocolo para ATM as radiografias transcranianas. Eram poucos os aparelhos de tomografia computadorizada e com preços que limitavam o uso. Na atualidade técnicas muito precisas como as imagens por "Cone Bean", que permitem a reconstrução tridimensional dos tecidos duros das estruturas cérvico-cranianas e a Imagem por Ressonância Magnética, que permite visualizar tecidos moles. Hoje estão disponíveis, por custo cada vez mais acessível, num maior número de localidades. Com isso o diagnóstico ficou mais preciso e o prognóstico mais realista. Os tratamentos tornaram-se mais específicos.
As placas reposicionadoras de disco articular, antes utilizadas de forma extensiva, passaram a ter uma indicação tão restrita que hoje só são utilizadas em casos criteriosamente selecionados. Paradoxalmente, as placas de relaxamento continuam a ser, apesar de ainda não ser claro o mecanismo de ação, amplamente utilizadas, e pode-se dizer que, por sua popularidade, serem até mesmo sobreutilizadas, o que prejudica o prognóstico, uma vez que outros métodos de tratamento são a primeira escolha para algumas disfunções específicas. Infelizmente, pela desassociação da oclusão como fator etiológico das DTMs, muitos autores desprezaram os critérios de confecção das placas oclusais, como a utilização de articulador para o enceramento e ajustes. Profissionais experientes têm a percepção que estas opiniões são apenas para ressaltar que oclusão (quase) não é o fator desencadeante (mas pode ser um fator perpetuante) das DTMs, mas é perigoso para os iniciantes na profissão e podem produzir iatrogenia em placas mal equilibradas.

A evolução da neurofisiologia permitiu que hoje compreendamos razoavelmente bem a influência da sensibilização central na cronificação da dor. Esta ocorre no neurônio de segunda ordem, no corno dorsal da medula ou no seu equivalente no núcleo sensitivo do trigêmeo. Uma desrregulação dos sistemas endógenos moduladores de dor, suprasegmentares, no tronco encefálico e cérebro, permitem a cronificação da dor. Parece serem três as principais formas de estimular os núcleos supressores de dor: os antidepressivos tricíclicos, a acupuntura e o TENS. Todos modulam a dor em nível segmentar por estímulos descendentes a partir dos núcleos suprasegmentares: Recomendamos que os profissionais da área de saúde envolvidos com o tratamento da dor conheçam estas três técnicas, para aplicá-las ou referir para um profissional habilitado.

As perspectivas futuras da especialidade visarão um diagnóstico diferencial mais preciso, com um 
melhor esclarecimento dos fatores etiológicos e imagens mais acuradas. Um melhor prognóstico dependerá do avanço da neurofisiologia e da farmacoterapia. $\mathrm{O}$ dentista continuará sendo o profissional responsável pelo paciente, embora cada vez mais a equipe multidisciplinar será necessária para o gerenciamento da Dor Orofacial.

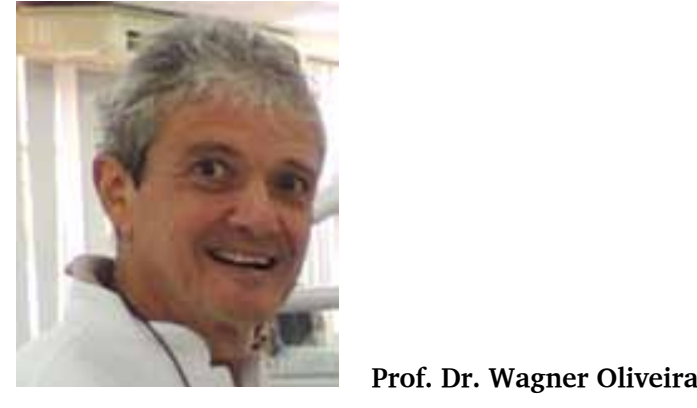

